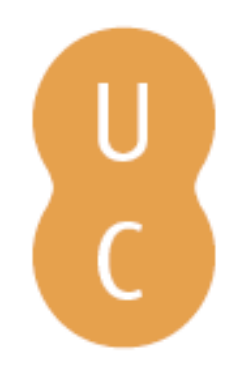

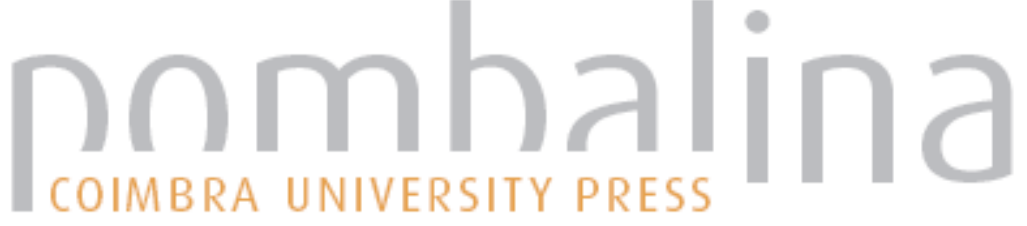

\section{An argument for intersubjective conditions of self-consciousness}

Autor(es): $\quad$ Lailach-Hennrich, Andrea

Publicado por: Imprensa da Universidade de Coimbra

URL persistente:

URI:http://hdl.handle.net/10316.2/31633

DOI:

DOI:http://dx.doi.org/10.14195/978-989-26-0205-9_11

Accessed : $\quad$ 26-Apr-2023 15:42:26

A navegação consulta e descarregamento dos títulos inseridos nas Bibliotecas Digitais UC Digitalis, UC Pombalina e UC Impactum, pressupõem a aceitação plena e sem reservas dos Termos e Condições de Uso destas Bibliotecas Digitais, disponíveis em https://digitalis.uc.pt/pt-pt/termos.

Conforme exposto nos referidos Termos e Condições de Uso, o descarregamento de títulos de acesso restrito requer uma licença válida de autorização devendo o utilizador aceder ao(s) documento(s) a partir de um endereço de IP da instituição detentora da supramencionada licença.

Ao utilizador é apenas permitido o descarregamento para uso pessoal, pelo que o emprego do(s) título(s) descarregado(s) para outro fim, designadamente comercial, carece de autorização do respetivo autor ou editor da obra.

Na medida em que todas as obras da UC Digitalis se encontram protegidas pelo Código do Direito de Autor e Direitos Conexos e demais legislação aplicável, toda a cópia, parcial ou total, deste documento, nos casos em que é legalmente admitida, deverá conter ou fazer-se acompanhar por este aviso. 
Edmundo Balsemão Pires

Burkhard Nonnenmacher

Stefan Büttner-von Stülpnagel

Editors

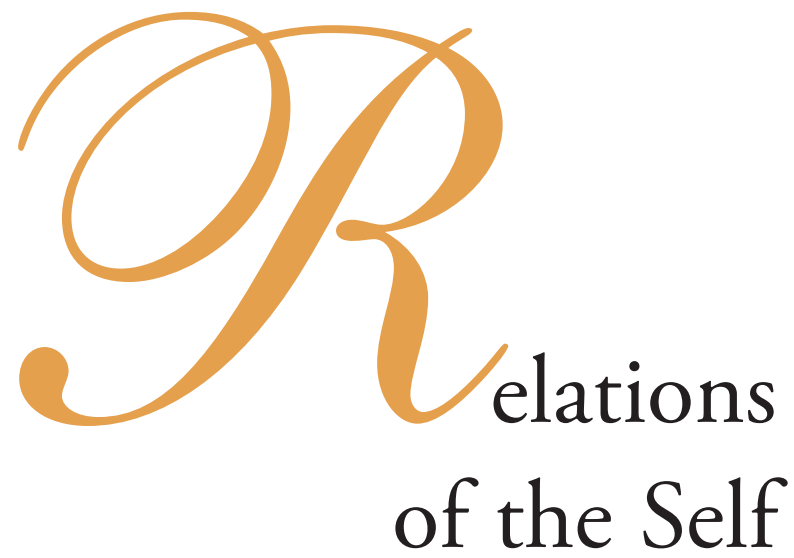




\section{Andrea Lailach-Hennrich}

Berlin

\section{AN ARGUMENT FOR INTERSUBJECTIVE CONDITIONS OF SELF-CONSCIOUSNESS}

In Mind, Self, and Society Mead explains his project by saying that a theory of mind cannot neglect the social nature of the mind if it is "to render an acceptable account of mind possible at all." How are we to understand that? Just what connection could there be between social society and an acceptable explanation of consciousness and self-consciousness? In this paper, I shall offer an argument that answers this question in the following way: In order to have self-consciousness, a subject must interact with other subjects in intersubjective ways. It is a necessary condition of the self-ascription of psychological properties that a subject is able to ascribe psychological properties to other subjects. In this formulation, the question of the social nature of the mind is a question about the intersubjective conditions of self-consciousness.

The question thus has a clear epistemological orientation. The postulation of intersubjective conditions reveals itself to be a possible way of dealing with the circularity problem of selfascription that results from a solitary justification of the knowledge of one's own mental states. Thus, if we intend to explain the mind adequately, as Mead demands, we must look at its intersubjectively conditioned nature.

The argument $\mathrm{SB}_{\mathrm{IN}}$ runs:

1. A subject $S$ only has self-consciousness when $S$ can think of itself as itself.

2. $S$ can only think of itself as itself when $S$ has both concepts that could apply to things different from it, and concepts that could apply to subjects that are different from it.

3. S only has concepts that could apply to things and subjects that are different from it if $S$ interacts with things and reciprocally interacts with subjects that are different from it.

Ergo:

1. If $S$ has self-consciousness, then $S$ has had contact with things and reciprocally interacts with subjects that are different from it.

\footnotetext{
${ }^{1}$ Mead, G. H., “Mind, Self, and Society”, Chicago: The University of Chicago Press 1967, p. 133.
} 
The argument is logically valid. Its power to persuade thus depends on the plausibility of the particular premises. However, before these are investigated more closely, two ways of reading the argument should be distinguished.

The first way of reading the argument takes it to be one that challenges an egoistic perspective. According to this way of reading, the argument shows that the concept of oneself must be a relational concept. One cannot think of oneself without also having concepts of some other. Only in this way can the distinction be made between my self and others, a distinction that is fundamental for self-consciousness. ${ }^{2}$ But for this distinction, it is not necessary to distinguish "things different from S" and "individuals different from S".

It is only through the second way of reading the argument, however, that it turns into one for the intersubjectively conditioned nature of self-consciousness. This way of reading takes the further distinction between "things different from S" and "subjects distinguished from $S$ ” to be necessary. It takes it to be necessary for two reasons. First, $S$ is only in a position to think of itself in contrast to other subjects if $S$ has the concept of a psychological subject - in addition to those concepts that apply to things that are different from S. The second reason is one that concerns the definition of intersubjectivity. It is assumed that selfconsciousness only has intersubjective conditions if it can be shown that reciprocal interactions with other subjects are necessary for a subject's having a concept of itself.

\section{Discussion of the Premises}

In the following, I will show how the argument can be made plausible.

The first premise contains the definition of the concept "self-consciousness". A self-conscious subject can refer to itself as itself. Therefore it has a concept of itself. That means, more precisely, that the subject understands certain mental states as its own and considers itself as that which has mental states. The formulation "think of itself as itself" is supposed to rule out Castañedacases. ${ }^{3}$ Defenders of a non-conceptual self-consciousness, in particular, have argued against the definition contained in this premise. They claim that a subject already has self-consciousness when it has a perspective on its own experience. They point out that every phenomenal experience is characterized by a subjective perspective, and thus that there is always an experiencing ,I that experiences sensations, emotions, and perceptions as its own. Insofar as one is ready to admit that, they claim, one should be willing to characterize this subjective perspective as a form of self-consciousness. But for such self-consciousness, a concept of oneself is not at all necessary. If one intends to defend this proposal, however, one is faced with the following problem: One has to explain how the specific structure of reflexive self-reference can be

\footnotetext{
${ }^{2}$ See also Baker: “... the first-person perspective is relational in a certain sense. One cannot think of oneself as oneself* without concepts of other things by means of which to distinguish things as being different from oneself (...). It is only over and against other things in the world that one stands as a subject with a first-person perspective.” L.R. Baker, “The First-Person Perspektive: A Test for Naturalism”, American Philosophical Quaterly, 35, 1998, 327-346, p. 340 .

${ }^{3}$ Cf., H.-N. Castañeda, “»He«: A Study on the Logic of Self-consciousness, in: Ratio, Oxford 1966, 130-157, "Indicators and Quasi-indicators", in: American Philosophical Quarterly 4, 1967, 121-158.
} 
determined without recourse to conceptual competence on the part of the subject. That means one should be able to show that there can be de se beliefs that are not bound to the "as-structure".

There is a chance of showing that if one accepts this there is something like an immediate, identification-free self-reference as the particular manner in which a subject is given to itself. The self-reference must be identification-free, because identification proceeds through predication, which is supposed to be ruled out in accordance with the pre-conditions of non-conceptual self-consciousness. However, it is hard to see how it could be determined at all that there is such an identification-free self-reference. The assumption of a special, subjective way of experiencing no longer helps here if this way of experiencing can only be revealed in form of a self-ascription. For in this case, the self-reference would be the content of a belief de se, which means that it could not be non-conceptual.

If one wants to avoid this objection, one must point to a particular kind of behavior that can be seen as sufficient reason for the ascription of self-consciousness. Bermudez argues in this direction. ${ }^{4}$ For the assumption of a non-conceptual self-consciousness, he asserts, it is enough "to identify ways of behaving in pre- or non-linguistic life-forms, for whom inference to the best explanation makes necessary the ascription of states with non-conceptual firstperson content". ${ }^{5}$ What sorts of ways of behaving could these be? According to Bermudez, they are those that show that (1) the subject acts on the basis of proprioceptive information, that (2) it can draw a boundary between self and not-self, and that (3) it experiences itself as someone that has reactive attitudes. These sorts of self-conscious ways of behaving are supposed to then be identifiable in the domain of social interactions in which pre-linguistic and non-linguistic subjects are involved. Within such social interactions, inference to the best explanation makes necessary the assumption "that such subjects could apply the relevant psychological categories to themselves and others". ${ }^{6}$ There are two problems here. First, one requires a criterion of distinction for the application of the concepts "cooperation" and "social interaction" to social ways of behaving. It would be natural here to stipulate that interaction applies to a reciprocal intentional reference, while reserving the term "cooperation" for courses of behavior that are organized on an instinctual basis, for what reason whose explanation does not require the assumption of intentionality. One could argue then along with Mead that the only social behavior that is actually interactive in the required sense is communication between two subjects, because only communication guarantees reciprocity. And reciprocity means that a subject both acts intentionally and can relate the reactions of others back to its own action. The second problem with Bermudez's proposal becomes clear when one asks about the conditions for the application of psychological categories. Generality is one condition that should be fulfilled. In order for there to be generality, one must not only assume that the subject can use psychological categories in a concrete situation; one must assume that the subject could use the categories as well if the corresponding behavioral situation were not present. I don't see how such generality can be attained without the possession of concepts.

${ }^{4}$ J.L. Bermúdez, “The paradox of self-consciousness”, Cambridge Mass., 1998.

5 J.L. Bermúdes, "Nichtbegriffliche Selbsterfahrung und das Paradox des Selbstbewusstseins", in: Selbst und Gehirn, hrsg. v. A. Newen u. K. Vogeley, Paderborn 2000, 79-99, S. 83.

${ }^{6}$ Bermúdes, 2000, p. 91. 
At this point, one might object that the line of argument sketched so far fails to do justice to the subjective perspective on experience. However, one can explain the subjective perspective on experience without ascribing the application of psychological categories to subjects. Baker has made an interesting proposal in this context. She distinguishes two steps of I-phenomena: weak and strong I-phenomena. ${ }^{7}$ We ascribe weak I-phenomena to creatures who manifest problemsolving behavior in specific contexts and act out of an I-centered standpoint. They just experience things from their own perspective, without however possessing a concept of themselves or having the capacity to recognize themselves as themselves. Thus, they do not apply psychological categories. With regard to strong I-phenomena, by contrast, the subject can not only distinguish between the first- and third-person perspective, it can also conceptualize them. That means it can understand itself as someone that has I-phenomena. Therefore it has a concept of itself. The generality that is bound up with conceptualization allows then for a neutralization of perspective and context-dependence. For that reason, beings which exhibit strong I-phenomena can apply psychological categories to themselves and other subjects. It thus suffices for the best explanation to ascribe weak I-phenomena to those beings who do not (yet) have a concept of themselves. The ascription of self-consciousness, then, goes with the ascription of strong I-phenomena, which implies that the subject can think of itself as itself.

The second premise contains the condition that is formulated by Strawson and Evans. According to this condition, a psychological predicate can only meaningfully be applied to oneself if it can also be used for the ascription of mental states to other subjects. The justification here is that only when this condition is fulfilled there is a guarantee that a psychological predicate has a meaning that transcends particular perspectives. Predicates that change their meaning according to the perspective of the ascription have several disadvantages. One disadvantage is that the behavior of other subjects could no longer be interpreted, at least not when psychological predicates are in play. That would have wide-ranging consequences for the understanding of other subjects, since indeed "intend" and "believe" are also psychological predicates. A further disadvantage is that mental states could no longer be unambiguously identified, because the criterion of identity for mental states would fall away. However, this criterion is supposed to hold to the same extent and intelligibly for every subject that intends to ascribe mental states to oneself and to others. In order to avoid these consequences, the following condition must be fulfilled:

“... it is a necessary condition of one's ascribing states of consciousness, experience, to oneself, in the way one does, that one should also ascribe them, or be prepared to ascribe them, to others who are not oneself."

What is here initially assumed as a condition is that all predicates by which mental states are ascribed must have one and the same meaning. Strawson writes to that effect: "That means not less than it says. It means, for example, that the ascribing phrases are used in just the same sense when the subject is another as when the subject is oneself'. ${ }^{9}$ But the decisive point is the following. According to Strawson, in order for the condition mentioned to be fulfilled, there

\footnotetext{
${ }^{7}$ Baker, 1998, p. 253.

${ }^{8}$ P.F. Strawson, Individuals: An Essay in Descriptive Metaphysics, London 1959, p. 99.

${ }^{9}$ Ibid.
} 
must be a correlation between "the idea of a predicate (...) and that of a range of distinguishable individuals of which the predicate can be significantly, though not necessarily truly, affirmed." ${ }^{10}$ Evans further specifies the relationship between the idea of a predicate and the idea of a range of distinguishable individuals with the concept of the Generality Constraint:

"That anyone who has a grasp of the concept of being F must be able to understand what it is for an arbitrary proposition of the form $>\mathrm{a}$ is $\mathrm{F}<$ to be true (where a is an idea which he possesses of an object). The Generality Constraint requires us to see the thought that a is $\mathrm{F}$ as lying on the intersection of two series of thoughts: The thoughts that a is F, that a is G, that a is $\mathrm{H}, \ldots$, on the one hand, and the thoughts that a is $\mathrm{F}$, that $\mathrm{b}$ is $\mathrm{F}$, that $\mathrm{c}$ is $\mathrm{F}, \ldots$, on the other." ${ }^{11}$

Here we are dealing with the second series of thoughts mentioned by Evans. (The first has to do with the question of whether the use of "I" is immune to error through misidentification.) One can only possess the concept of being $F$ if one knows what it means for other persons to be F. It becomes clear in this way how the correlation that Strawson requires is to be understood. The assumption of a series of individuals is a necessary condition for the meaningful application of psychological predicates. For it is only because of the fact that predicates are ascribable to different persons that the condition of general applicability is fulfilled. General applicability, in turn, is necessary in order to fix the content of psychological predicates. This is because it guarantees that the predicates do not change their meaning with every ascription. It follows from all this that the assumption of a series of distinguishable individuals, where each of whom could be the object of the ascription of mental predicates, is also required for the application of psychological predicates to oneself.

The third premise can then be argued for with the help of Mead's theory of the self. In this connection, Mead pursues two connected strategies. One consists in arguing that a subject can only form concepts in the context of intersubjective processes of action. The reason for this is that the subject must be conscious of the meaning of the concepts in order to entertain them. Mead is thus looking for a behavior that can make possible self-relatedness. He assumes that this behavior must also be constitutive for self-consciousness. He ultimately finds the behavior he is looking for in the exchange of gestures, in particular, in the exchange of vocal gestures. A vocal gesture allows the subject to react to her own stimulus in the same manner that others do. Meaning can so be understood as the mutual response of the beings participating in the exchange of gestures. However, that does not yet answer the question of whether the vocal gesture has an identical meaning for all beings that are involved in the exchange. What is required for identical meaning is a condition that makes it possible for the subject to understand the communicative intention of the gesture. In addition, the interpretation must be reciprocal, since it is assumed that identical meaning is only present when the subjects are aware of the communicative intention of their respective other. According to Mead, a gesture possesses identical meaning only on the basis of a reactive adaptation, and this in turn is only possible if the speaker can place himself in the perspective of the hearer and anticipate his interpretation. With that, the condition that Mead is looking for is stated. It is the capacity for taking the perspectives of the other that guarantees the reciprocity of interpretive expectations

\footnotetext{
${ }^{10}$ Ibid.

${ }^{11}$ G. Evans, "The Varieties of Reference”, Oxford 1996 (repr.), p. 209.
} 
and makes possible an identical meaning of gestures. Without this capacity, the semantic expectations of other speakers could play no guiding and corrective role in fixing the meaning of one's own gesture. Speakers are thus conscious of the meaning of their gestures only when they take the perspective of the other participant in communicative interactions.

With that, the argument for the third premise could be considered to be finished. But Mead proceeds in another manner. He wants to show that self-consciousness, just like meaning, rests on the social behavior of the exchange of gestures. For this reason, I spoke of two related strategies. His theory of meaning and the conception of self-consciousness do not stand in a deductive relation to one another. Such a deductive relation implies that selfconsciousness has intersubjective conditions only because the possession of the concept of the self presupposes a meaning with an intersubjective structure. Instead, what Mead says is that the capacity for taking the perspective of the other is the basis both for identical meaning and self-consciousness. Mead imagines the formation of a self-concept in the following manner: When a subject is confronted with other subjects, she is challenged to fix her own attitudes. That means she has to interpret them. For that, she includes in the interpretation both her own response to the other and the intentions of the other. Her own response works in turn on the other and possibly challenges it to modify its own requests. The analysis of one's own attitudes thus proceeds reciprocally. If there were no resistance or check through some other, however, a subject would have no opportunity to become conscious of her own subjective experiences. It is only through the push to analyze one's own attitudes that is elicited by the requests of the other that the subject becomes conscious of her own subjective experiences. It should be clear by now that this becoming-conscious cannot happen without conceptual competence. The self-relatedness that is necessary for self-consciousness can only occur in circumstances where creatures understand one another in reciprocal communicative intent, and they do so because they are in the possession of identical meanings.

Let's now summarize: The capacity for taking the perspective of the other is a presupposition both for the analysis of one's own attitudes as well as for meanings. From this it follows that, in order for a subject to be able to ascribe psychological properties to itself, it must be able to ascribe psychological properties to others, and to do that, it must stand in an interpretive - more precisely, a communicative - relation with others. Thus, even for the selfascription of psychological properties, it is necessary that a subject interact in intersubjective ways with others. If the ascription takes place through mental predicates, the condition of the general applicability of predicates dictates that a psychological predicate can only be meaningfully applied to oneself if it is also used for the ascription of mental states to others.

With that, I have reached the end of my paper. I hope it has become clear how the argument for intersubjective conditions of self-consciousness can be defended. However, in closing, one question remains to be clarified: can the argument actually solve the circularity problem that results from a solitary justification of the knowledge of one's own mental states? I think that it can. As Mead has shown, the self-relatedness that is constitutive of selfconsciousness can only be attained in circumstances in which other individuals provide the stimulus for becoming-conscious of one's own subjective experience, and that occurs in communicative interactions. 